\title{
NUTRIENT STOICHIOMETRY OF NEPENTHES SPECIES FROM A BORNEAN PEAT SWAMP FOREST
}

\begin{abstract}
Francis Q. BREARLey $\bullet$ School of Science and the Environment $\bullet M$ anchester $M$ etropolitan U niversity - Chester Street • M anchester • M 15 SD • United K ingdom • f.q.brearley@ mmu.ac.uk Muhammad Mansur - Botany Division - Research Center for Biology • Indonesian Institute of Sciences • Cibinong Science Center • J alan R aya J akarta-B ogor, K m 46 • Cibinong 16911

-Indonesia・mansurhalik@yahoo.com
\end{abstract}

Keywords: Indonesia, micronutrients, nitrogen, phosphorus, wetlands.

\section{A bstract}

To shed light on the nature of nutrient limitation in carnivorous plant communities, we collected data on foliar nutrient concentrations and ratios from three Nepenthes species and one natural hybrid growing in peat swamp forests of southern B orneo. Due to their low foliar nitrogen concentrations and very low nitrogen:phosphorus ratios, our data strongly suggest that these species are limited by nitrogen availability.

The carnivorous habit and uptake of nutrients from invertebrate prey items is an evolutionary response to the nutrient-poor environments in which some plants find themselves. To determine patterns of nutrient use and nutrient limitation in carnivorous plants, nutrient concentrations and stoichiometry (ratios between nutrients) can be assessed (Koerselman \& M euleman 1996; Willby et al. 2001; Olde Venterink et al. 2003; Güsewell 2004). From a review of the literature, Ellison (2006) suggested that most carnivorous plants are phosphorus (P) or nitrogen (N) + P limited but he presented minimal data from Nepenthes pitcher plants. Osunkoya et al. (2007) went some way towards rectifying this deficit by providing data on $\mathrm{N}, \mathrm{P}$, and potassium $(\mathrm{K}$ ) concentrations from six species in B runei that suggested that Nepenthes are actually $\mathrm{N}$ limited due to their very low $\mathrm{N}$ concentrations and low $N$ :P ratios. However, this is currently the only study with multi-element data from Nepenthes species. In this paper we provide extra much-needed information on Nepenthes leaf nutrients from three species and one natural hybrid found in a peat swamp forest in Indonesian B orneo to improve generalizations about nutrient relationships in this fascinating plant genus.

In the Sebangau peat swamp forest in Central Kalimantan, Indonesia ( $\left.2^{\circ} 18^{\prime} \mathrm{S} ; 113^{\circ} 55^{\prime} \mathrm{E}\right)$, three species of Nepenthes, N. ampullaria Jack, N. gracilis Korth. (see Fig. 1), and N. rafflesiana Jack are found along with one natural hybrid, N. $\times$ hookeriana Lindl. (M ansur 2008). Leaf material (all leaves were estimated to be less than one year old) was collected from individuals of these four 'species' in A pril-M ay 2006. A bout $40 \mathrm{mg}$ of leaf material was digested in $2.5 \mathrm{ml}$ concentrated sulphuric acid with a lithium sulphate/selenium $(100: 1)$ catalyst at $375^{\circ} \mathrm{C}$ for 4 hours, diluted with deionized water, and analyzed for nutrient concentrations on a Dionex ICS-2000 I on Chromatography System (for N) or a Varian V ista AX Inductively Coupled Plasma Optical Emission Spectrometer (for all other elements). Differences in nutrient concentrations between species were analyzed by one-way A NOVA s implemented in M initab 15.1 and data was $\log _{10}$ transformed where needed to improve homogeneity of variances. 


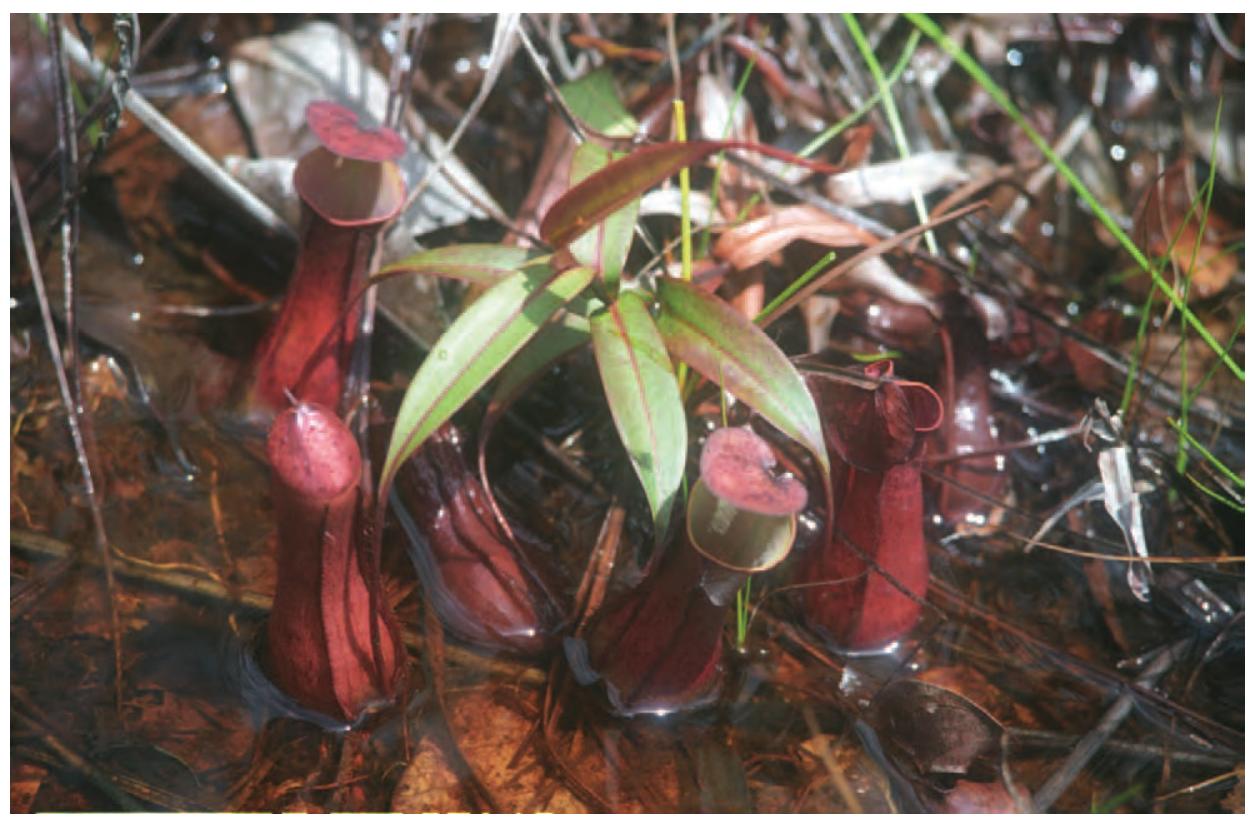

Figure 1: Nepenthes gracilis growing in peat swamp forest at Sebangau, Central Kalimantan, Indonesia.

Table 1 shows the nutrient concentrations of the four 'species'. Nitrogen, phosphorus, and calcium all showed generally low concentrations whereas potassium and magnesium were around, or above, average (Grimshaw et al. 1989; Pugnaire 2001; B roadley et al. 2004). There were no significant differences in N concentrations between the 'species'. Phosphorus concentrations were greatest in N. gracilis and N. rafflesiana as were K concentrations (although differences for K were not significant). N. ampullaria showed the lowest concentrations for many of the nutrients, including the micronutrients.

$B$ ased on prior analysis of species and life-forms from temperate regions, many from wetlands (K oerselman \& M euleman 1996; Willby et al. 2001; Olde Venterink et al. 2003; Tessier \& Raynal 2003), our data suggest $N$ limitation for all the 'species' found as they all had very low $N$ concentrations (less than $0.85 \%$ in all individuals). In addition, the foliar N:P ratios of 3.3 to 9.3 were exceptionally low (significantly lower values were found in N. gracilis and N. rafflesiana than $\mathrm{N}$. ampullaria and $\mathrm{N} . \times$ hookeriana) where the critical value of $N: P$ is 14 , below which $N$ is considered limiting to plant growth (Koerselman \& M euleman 1996) although this value may be lower in drier forests (Tessier \& Raynal 2003). P concentrations were also very low in N. ampullaria at levels that are considered limiting ( $<1 \mathrm{mg} \mathrm{g}^{-1}$; Willby et al. 2001) but the low N:P ratio still suggests greater limitation by $\mathrm{N}$ in this species. There was no indication of $\mathrm{K}$ being a limiting nutrient in any of the 'species' examined (>0.8\%, $\mathrm{N}: \mathrm{K}<2: 1$, and $\mathrm{K}: \mathrm{P}>3.4$; Willby et al. 2001; Olde Venterink et al. 2003).

Our results therefore corroborate the data of Osunkoya et al. (2007) who found average nutrient concentration across six species in $\mathrm{B}$ runei to be $\mathrm{N}=0.81 \%, \mathrm{P}=1.9 \mathrm{mg} \mathrm{g}^{-1}$, and $\mathrm{K}=1.08 \%$ with an $N$ :P ratio of less than 5; Osunkoya et al. (2007) al so collected leaves from peat swamp forest but these were combined with plants from heath forest for analysis. Their $\mathrm{N}$ and $\mathrm{P}$ values were higher than ours although their $\mathrm{K}$ values were lower and overall they considered that Nepenthes species 
Table 1. Nutrient concentrations and stoichiometric ratios for nine plant nutrients in four 'species' of Nepenthes pitcher plants in the Sebangau peat swamp forest, Central Kalimantan, Indonesia. Different letters within a row indicate statistically significant differences $(p<0.05)$ using Tukey's tests (on $\log _{10}$ transformed data where required).

\begin{tabular}{|l|c|c|c|c|}
\hline & N. ampullaria & N. gracilis & N. $\times$ hookeriana & N. rafflesiana \\
\hline $\mathrm{N}(\%)$ & $0.50 \pm 0.07(\mathrm{a})$ & $0.65 \pm 0.07(\mathrm{a})$ & $0.67 \pm 0.08(\mathrm{a})$ & $0.63 \pm 0.05(\mathrm{a})$ \\
\hline $\mathrm{P}\left(\mathrm{mg} \mathrm{g}^{-1}\right)$ & $0.59 \pm 0.07(\mathrm{a})$ & $1.52 \pm 0.36(\mathrm{~b})$ & $0.85 \pm 0.14(\mathrm{ab})$ & $1.16 \pm 0.09(\mathrm{~b})$ \\
\hline $\mathrm{K}(\%)$ & $2.61 \pm 0.21(\mathrm{a})$ & $4.70 \pm 0.29(\mathrm{a})$ & $2.29 \pm 0.33(\mathrm{a})$ & $5.90 \pm 1.68(\mathrm{a})$ \\
\hline $\mathrm{N}: \mathrm{P}$ & $8.49 \pm 0.41(\mathrm{~b})$ & $4.65 \pm 0.59(\mathrm{a})$ & $8.09 \pm 0.39(\mathrm{~b})$ & $5.42 \pm 0.32(\mathrm{a})$ \\
\hline $\mathrm{N}: \mathrm{K}$ & $0.19 \pm 0.01(\mathrm{ab})$ & $0.14 \pm 0.01(\mathrm{a})$ & $0.30 \pm 0.01(\mathrm{~b})$ & $0.16 \pm 0.06(\mathrm{a})$ \\
\hline $\mathrm{K}: \mathrm{P}$ & $45.1 \pm 2.3(\mathrm{a})$ & $34.6 \pm 5.3(\mathrm{a})$ & $27.1 \pm 0.6(\mathrm{a})$ & $49.8 \pm 13.9(\mathrm{a})$ \\
\hline $\mathrm{Ca}\left(\mathrm{mg} \mathrm{g}^{-1}\right)$ & $0.57 \pm 0.09(\mathrm{a})$ & $1.51 \pm 0.86(\mathrm{a})$ & $6.86 \pm 1.13(\mathrm{~b})$ & $1.67 \pm 0.31(\mathrm{a})$ \\
\hline $\mathrm{Mg}\left(\mathrm{mg} \mathrm{g}^{-1}\right)$ & $2.05 \pm 0.38(\mathrm{a})$ & $5.10 \pm 0.36(\mathrm{~b})$ & $6.61 \pm 0.58(\mathrm{~b})$ & $9.01 \pm 2.47(\mathrm{~b})$ \\
\hline $\mathrm{Fe}\left(\mu \mathrm{g} \mathrm{g}^{-1}\right)$ & $7.7 \pm 0.8(\mathrm{a})$ & $40.5 \pm 10.6(\mathrm{~b})$ & $60.9 \pm 7.9(\mathrm{~b})$ & $73.4 \pm 31.0(\mathrm{~b})$ \\
\hline $\mathrm{M} \mathrm{n}\left(\mu \mathrm{g} \mathrm{g}^{-1}\right)$ & $9.7 \pm 1.6(\mathrm{a})$ & $57.3 \pm 23.9(\mathrm{~b})$ & $251 \pm 24(\mathrm{c})$ & $172 \pm 31(\mathrm{c})$ \\
\hline $\mathrm{Ni}\left(\mu \mathrm{g} \mathrm{g}^{-1}\right)$ & $0.41 \pm 0.05(\mathrm{a})$ & $2.13 \pm 0.74(\mathrm{ab})$ & $4.99 \pm 1.93(\mathrm{~b})$ & $2.45 \pm 0.99(\mathrm{ab})$ \\
\hline $\mathrm{Zn}\left(\mu \mathrm{g} \mathrm{g}^{-1}\right)$ & $5.9 \pm 0.6(\mathrm{a})$ & $21.1 \pm 6.2(\mathrm{a})$ & $66.5 \pm 9.3(\mathrm{~b})$ & $17.2 \pm 4.1(\mathrm{a})$ \\
\hline
\end{tabular}

were $\mathrm{N}$ limited in contrast to other carnivorous plant genera which appear to be $\mathrm{P}$ or $\mathrm{N}+\mathrm{P}$ limited (Ellison 2006).

M ost micronutrient concentrations in the Nepenthes leaves were normal to low for plant tissues and there were no remarkable concentrations. It was interesting to note that, for $\mathrm{N} . \times$ hookeriana, only in some cases ( $\mathrm{P}, \mathrm{M} \mathrm{g}, \mathrm{Fe}$ ) were the values intermediate between that of its 'parent' species $\mathrm{N}$. ampullaria and $\mathrm{N}$. rafflesiana. In terms of other nutrients ( $\mathrm{C}$ a and other micronutrients) it had the highest concentrations; perhaps reflecting some aspect of hybrid vigor (Chen 2010).

In conclusion, our results suggest that $\mathrm{N}$ is the limiting nutrient for Nepenthes in contrast to other carnivorous plants that seem to be $\mathrm{P}$ or $\mathrm{N}$ limited. This hypothesis may not include montane $\mathrm{N}$ epenthes that, somewhat surprisingly, appear to have higher foliar $\mathrm{N}$ concentrations (Clarke et al. 2009). However, the only way to fully determine the nature of nutrient limitation is through fertilization experiments al though this presents difficulties of its own as differences have been found in plant responses to fertilization through the leaves as compared to the roots (A damec 1997). M ore work is clearly required on the mineral nutrition and nutrient stoichiometry of A sian pitcher plants.

A cknowledgements: CIM TROP are thanked for research permission and D avid M CK endry and Paul Warren are thanked for assistance with nutrient analyses.

\section{References}

A damec, L. 1997. M ineral nutrition of carnivorous plants: a review. B ot. R ev. 63: 273-299.

B roadley, M.R., Bowen, H.C., Cotterill, H.L., Hammond, J.P., M eacham, M.C., M ead, A., and White, P.J. 2004. Phylogenetic variation in the shoot mineral concentration of angiosperms. J. Exp. B ot. 55: 321-336. 
Chen, Z.J. 2010. M olecular mechanisms of polyploidy and hybrid vigor. Trends Plant Sci. 15: 57-71. Clarke, C.M ., Bauer, U., L ee, C.C., Tuen, A .A., Rembold, K., and M oran, J.A . 2009. Tree shrew lavatories: a novel nitrogen sequestration strategy in a tropical pitcher plant. Biol. L ett. 5: 632-635. Ellison, A.M . 2006. N utrient limitation and stoichiometry of carnivorous plants. Plant Biol. 8: 740-747. Grimshaw, H.M., Allen, S.E., and Parkinson, J.A. 1989. Nutrient elements. In Allen, S.E. (ed.) Chemical A nalysis of Ecological M aterials, $2^{\text {nd }}$ Edition, pp. 81-159. Blackwell Scientific Publications, Oxford, UK.

Güsewell, S. 2004. N :P ratios in terrestrial plants: variation and functional significance. N ew Phytol. 164: 243-266.

Koerselman, W., and M euleman, A.F.M. 1996. The vegetation N:P ratio: a new tool to detect the nature of nutrient limitation. J. A ppl. Ecol. 33: 1441-1450.

M ansur, M . 2008. Penelitian ekologi N epenthes di L aboratorium A lam Hutan Gambut Sabangau, Kereng B angkirai, Kalimantan Tengah. J. Teknol. Lingkung. 9: 67-73.

Olde Venterink, H., Wassen, M.J., Verkroost, A.W.M ., and de Ruiter, P.C. 2003. Species richnessproductivity patterns differ between $\mathrm{N}$-, $\mathrm{P}-$-, and $\mathrm{K}$-limited wetlands. Ecology 84: 2191-2199.

Osunkoya, O.O., Daud, S.D., Di-Giusto, B., Wimmer, F.L., and Holige, T.M . 2007. Construction costs and physico-chemical properties of the assimilatory organs of Nepenthes species in northern B orneo. A nn. B ot. 99: 895-906.

Pugnaire, F. 2001. Variability of inorganic nutrient concentrations in leaves. N ew Phytol. 150: 506-507. Tessier, J.T., and Raynal, D.J. 2003. U se of nitrogen to phosphorus ratios in plant tissue as an indicator of nutrient limitation and nitrogen saturation. J. A ppl. Ecol. 40: 523-534.

Willby, N.J., Pulford, I.D., and Flowers, T.H. 2001. Tissue nutrient signatures predict herbaceouswetland community responses to nutrient availability. N ew Phytol. 152: 463-481.

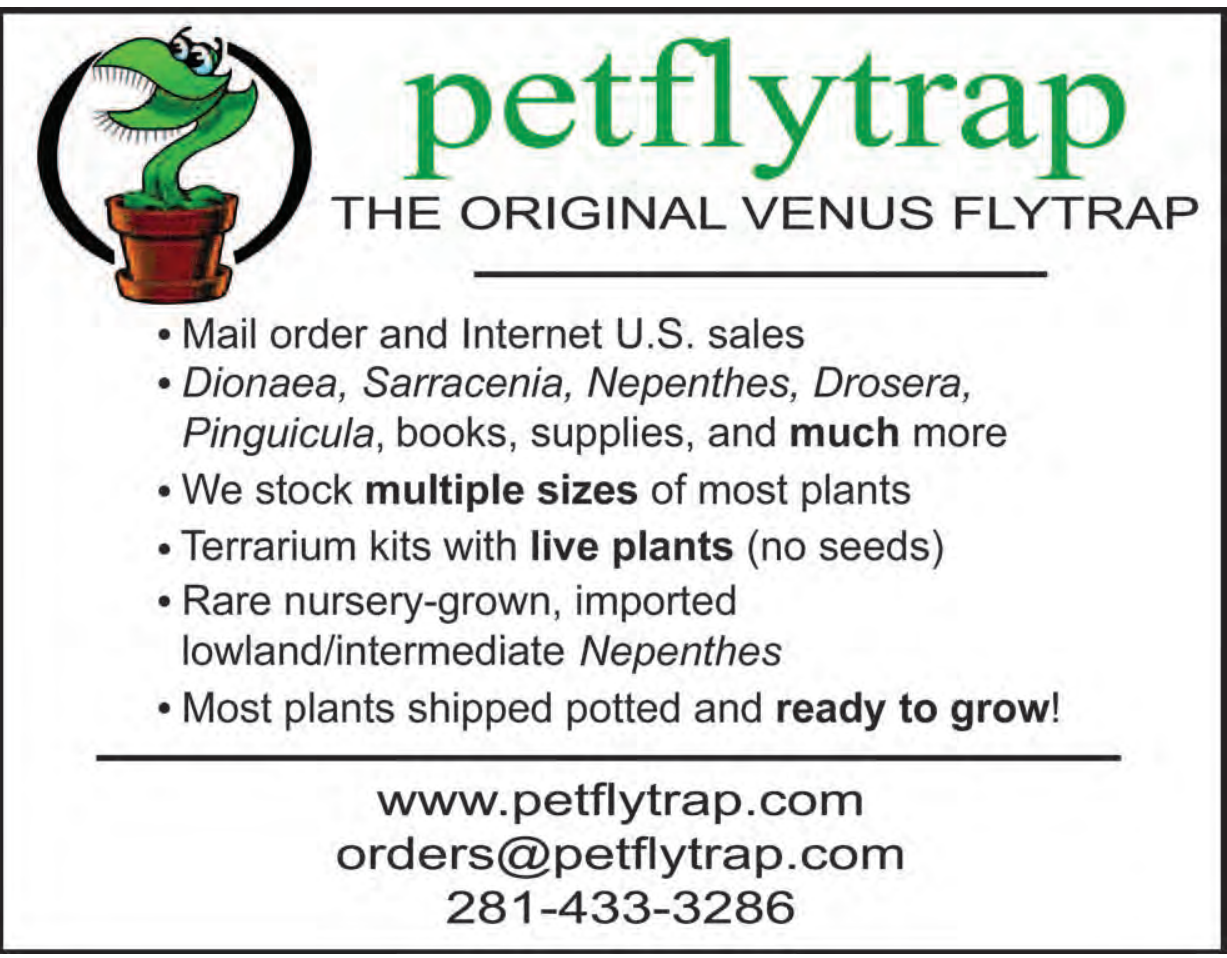

